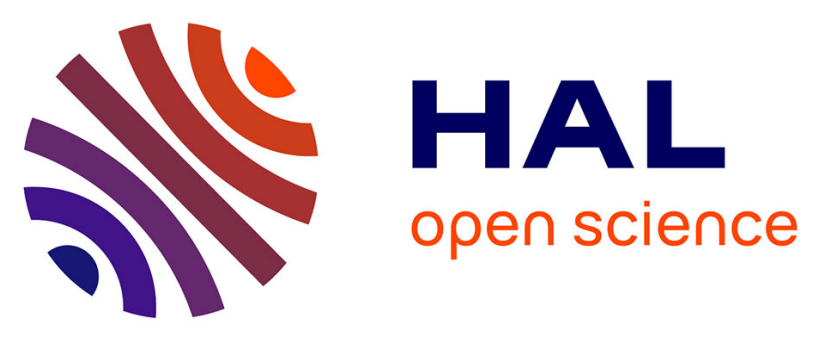

\title{
Acoustic, electrochemical and microscopic characterization of interaction of Arthrospira platensis biofilm and heavy metal ions
}

Nadèje Tekaya, Ibtissèm Gammoudi, Mohamed Braiek, Hakim Tarbague, Fabien Morote, Vincent Raimbault, Nawfel Sakly, Dominique Rebière, Hatem Ben Ouada, Florence Lagarde, et al.

\section{To cite this version:}

Nadèje Tekaya, Ibtissèm Gammoudi, Mohamed Braiek, Hakim Tarbague, Fabien Morote, et al.. Acoustic, electrochemical and microscopic characterization of interaction of Arthrospira platensis biofilm and heavy metal ions. Journal of Environmental Chemical Engineering, 2013, 1 (3), pp.609619. 10.1016/j.jece.2013.07.006 . hal-00878629

\section{HAL Id: hal-00878629 \\ https://hal.science/hal-00878629}

Submitted on 9 Mar 2018

HAL is a multi-disciplinary open access archive for the deposit and dissemination of scientific research documents, whether they are published or not. The documents may come from teaching and research institutions in France or abroad, or from public or private research centers.
L'archive ouverte pluridisciplinaire HAL, est destinée au dépôt et à la diffusion de documents scientifiques de niveau recherche, publiés ou non, émanant des établissements d'enseignement et de recherche français ou étrangers, des laboratoires publics ou privés.

\section{(1)(1) $\$(0)$}

Distributed under a Creative Commons Attribution - NonCommercial - ShareAlikel 4.0 


\title{
Acoustic, electrochemical and microscopic characterization of interaction of Arthrospira platensis biofilm and heavy metal ions
}

\author{
Nadèje Tekaya ${ }^{\mathrm{a}, \mathrm{b}, *}$, Ibtissèm Gammoudi ${ }^{c}$, Mohamed Braiek ${ }^{\mathrm{a}, \mathrm{b}}$, Hakim Tarbague ${ }^{\mathrm{c}}$, Fabien Moroté ${ }^{\mathrm{d}}$, \\ Vincent Raimbault $^{c}$, Nawfel Sakly ${ }^{\mathrm{b}}$, Dominique Rebière ${ }^{\mathrm{c}}$, Hatem Ben Ouada ${ }^{\mathrm{e}}$, Florence Lagarde ${ }^{\mathrm{a}}$, \\ Hafedh Ben Ouada $^{\mathrm{b}}$, Touria Cohen-Bouhacina ${ }^{\mathrm{d}}$, Corinne Dejous ${ }^{\mathrm{c}}$, Nicole Jaffrezic Renault ${ }^{\mathrm{a}}$ \\ ${ }^{a}$ Univ. Lyon, Institut des Sciences Analytiques, CNRS/ENS UMR 5280, Université Claude Bernard, 69100 Villeurbanne, France \\ ${ }^{\mathrm{b}}$ Univ. Monastir-Laboratoire des Interfaces et Matériaux Avancés, Faculté des Sciences de Monastir, Monastir 5000, Tunisia \\ ${ }^{c}$ Univ. Bordeaux, Laboratoire de l'Intégration du Matériau au Système, CNRS UMR 5218, IPB, Univ. Bordeaux 1, 33405 Talence, France \\ ${ }^{\mathrm{d}}$ Univ. Bordeaux 1, Laboratoire Ondes et Matière d'Aquitaines, CNRS UMR 5798, 351 crs Libération, 33405 Talence, France \\ e Univ. Monastir, Institut National des Sciences et Technologies de la Mer, Route de Khniss, Monastir 5000, Tunisia
}

A R T I C L E I N F O

Keywords:

Spirulina

Heavy metals

Admittance

Love wave

SEM

AFM

\begin{abstract}
A B S T R A C T
This study examines a biofilm of Arthrospira platensis and its interactions with cadmium and mercury, using electrochemical admittance spectroscopy technique combined with highly sensitive Love wave platform for the real time detection in liquid medium. Spirulina cells were immobilized via multilayers of polyelectrolyte ( $\mathrm{PEM}$ ) on $\mathrm{Si} / \mathrm{SiO}_{2}$ surface of both transducers and characterized using atomic force microscopy (AFM). Scanning electron microscopy (SEM) cell images revealed a first defense mechanism against cadmium at $10^{12} \mathrm{M}$ and it immediately takes place after $4 \mathrm{~s}$ from injection. The cyanobacteria biofilm becomes more conductive, due to an increase of polyphosphate bodies. An increase of density induces a decrease of frequency. Response time $\tau_{90 \%}$ of the biofilm toward $\mathrm{Cd}^{2+}$ was between 6 and 8 min, while it did not exceed a few seconds toward $\mathrm{Hg}^{2+}$ at $10{ }^{12} \mathrm{M}$. However, the initial rapid stage of mercury adsorption took $40 \mathrm{~s}$ to reach the saturated stage. Once external sorption reached the saturated stage, internal mercury uptake began; cations were transported across the cell membrane into the cytoplasm and a beta HgS precipitation took place, inducing conductivity biofilm decrease, and generating an increase of density, and thus a frequency decrease. SEM images revealed the beginning cell damage at $10{ }^{06} \mathrm{M}$ of cadmium and mercury.
\end{abstract}

\section{Introduction}

Environmental contamination with heavy metals has increased throughout the world due to the disposal of hazardous effluent into receiving waters $[1,2]$. Humans and animals are placed highly in the food chain and in particular the marine food chain. Non biodegradable, heavy metals accumulate in photosynthetic organ isms and transfer pollutants to consumers, including humans [3,4]. Indeed, substances such as cadmium or mercury have been classified as "priority hazardous substances" in Decision No. 2455/ 2001/EC [5] and Directive 2008/32/CE [6] for which industries should implement the necessary measures in order to reduce human anthropic activity. This is to preserve ecosystems. The U.S.

\footnotetext{
* Corresponding author at: Univ. Lyon, Institut des Sciences Analytiques, CNRS/ ENS UMR 5280, Université Claude Bernard, 69100 Villeurbanne, France. Tel.: +33 611901065 .

E-mail address: tekayanadeje@yahoo.fr (N. Tekaya).
}

Environmental Protection Agency's Roadmap for Mercury (July 5, 2006) promotes the reduction of mercury in processes and products. The overall goal of the Global Mercury Partnership of the United Nations Environment Program (Governing Council Decision 25/5, Nairobi, Kenya, February 16 20, 2009) is to reduce and eventually eliminate mercury use in products and processes and raising awareness of mercury free alternatives. Quality control of aquatic ecosystems requires tools of in situ continuous detection of contaminated environments, such as electrochemical [7] and electromechanical [8] platform detection.

Biosensors that are emergent micro technologies and charac terized by their small size, rapid response would allow continuous in situ toxicity monitoring. Recently, the development of whole cell biosensors has raised an increase interest. Microalgae such as Chlorella vulgaris, were used in various studies to develop whole cell biosensors for the control of toxic pollutants in aquatic environments [9 12]. Acoustic biodetection platform based on the bacteria Escherichia coli, has been developed for heavy metals detection in liquid medium [8]. For the same purpose, a dried 
biomass of cyanobacteria, Arthrospira platensis, called Spirulina, was used, in the present study.

The choice of Spirulina was based on two principal reasons: the first is that its biomass is environmental friendly, easier and harmless when manipulated. The second is that Spirulina has never been used as a bioreceptor for biosensors destined to directly detect pollutants. Most previous work employed algal and bacteria biomass to extract heavy metals from effluent solutions and for bioremediation. In fact, some microalgae and cyanobacteria species (such as Spirulina) can bind a wide range of heavy metals in contaminated ecosystems [13 16]. Spirulina is a Gram negative bacterium, also considered as blue green microalgae. Components found in the cell wall of Spirulina, such as peptydoglycan, teichuronic acid, teichoic acid, polysaccharides and proteins [17] which display mainly carboxylic, hydroxyl and phosphate groups $[18,19]$ may give algal wall binding properties. The cell wall of $A$. platensis has lots of negative carboxyl and phosphate groups, which are the dominant binding sites of toxic and metallic cations $[20,21]$. Furthermore, it has been found that microalgae possess a large surface area and high binding affinity [22], hence, they are a very effective biosorbents.

The results in this study help to provide an insight into the different interactions of dried biomass of A. platensis toward metallic cations using a combination of electrochemical, acoustic and microscopic tools. These three techniques have been chosen for specific reasons: first, admittance spectroscopy is a powerful tool for the study of dynamic electrical properties of dielectric materials [23]. Second, we applied acoustic wave platform in order to perform real time monitoring of the interaction of a heavy metal solution in contact with Spirulina biofilm. This will induce changes of its viscoelastic parameters. Due to their high sensitivity to surface perturbations and their transverse wave type (Shear horizontally polarized surface guided waves), sensors based on Love waves are ideally suited for (bio)chemical applications in gases and liquids [24]. The acoustic wave delay line was inserted in an oscillation loop and associated with a Polydimethylsiloxane (PDMS) chip, resulting in a small platform convenient for fast detection. Therefore, admittance and acoustic characterization was carried after each injection of heavy metals. Third, microscopic tools (AFM and SEM) were used as complementary techniques in order to provide information of the observed Spirulina cells (shape, size, biovolume, etc.). AFM is a powerful imaging tool that mechanically probes a surface with a high resolution to give morphological (or topographical) details of sample surface. It can also provide information about the mechanical surface properties at the local scale such as viscoelasticity, chemical composition and morphology evolution [25 30]. The AFM can also be used to capture dynamic aspects of individual biological molecules [31 $36]$ and their interactions with the environment [37,38] providing new insights into how macromolecules may work on the nanometer scale. AFM images were achieved to detect a change in Spirulina cells by measuring the elastic modulus via force curves at high concentrations of metallic cations. SEM was performed on Spirulina cells in order to characterize heavy metals effect at low concentrations $\left(10^{12} \mathrm{M}\right)$. This technology allows the observation of microstructural changes of biological samples in their natural state, under controlled conditions of temperature and pressure.

Spirulina cells were immobilized on the electrode surface ( $\mathrm{Si}$ / $\mathrm{SiO}_{2}$ ) and on Love wave sensors with a silicon oxide surface, via a polyelectolyte multilayers (PEM) using a layer by layer (LBL) method. The LBL assembly technique consists in the alternate deposition of polyanions and polycations from aqueous solutions to build ultrathin multilayered films on flat substrates [39]. Currently these films are intensely studied because of their many potential applications $[40,41]$ and recently, PEM were used to immobilize E. coli on $\mathrm{Si} / \mathrm{SiO}_{2}$ substrate [8].

\section{Materials and methods}

\section{Chemical and biological}

Two types of polyelectrolytes (PE) were used: polyallyla mine hydrochloride (PAH), a cationic type, and polysodium 4 styrenesulfonate (PSS), an anionic type. PAH and PSS have the molecular weight of about 56,000 and 70,000 respectively, and they were purchased from Sigma Aldrich. Solutions of PE $(5 \mathrm{mg} / \mathrm{mL}$ ) were prepared in TBS (Tris Buffered Saline) solution $(\mathrm{pH}=7.2$ at $0.15 \mathrm{M})$.

The stock solutions $(1 \mathrm{~g} / \mathrm{L})$ of cadmium $\left(\mathrm{Cd}^{2+}\right)$ and mercury $\left(\mathrm{Hg}^{2+}\right)$ as heavy metals, were prepared from $\mathrm{Cd}\left(\mathrm{NO}_{3}\right)_{2}\left(\mathrm{H}_{2} \mathrm{O}\right)_{4}$ and $\mathrm{Hg}\left(\mathrm{NO}_{3}\right)_{2}\left(\mathrm{H}_{2} \mathrm{O}\right)$ in TBS, purchased from Sigma Aldrich. Stock solutions were stored at $4{ }^{\circ} \mathrm{C}$ and dilutions were prepared before each series of measurements.

A. platensis (Compere 1968/3786 strain) or Spirulina, was cultivated under sterile conditions in Zarrouik liquid medium containing: (g/L) $\mathrm{NaNO}_{3}, 2.50 ; \mathrm{K}_{2} \mathrm{HPO}_{4}, 0.50 ; \mathrm{NaHCO}_{3}, 10.00 ; \mathrm{NaCl}$, 1.00; $\mathrm{MgSO}_{4} 7 \mathrm{H}_{2} \mathrm{O}, 0.2 ; \mathrm{CaCl}_{2} 2 \mathrm{H}_{2} \mathrm{O}, 0.02$; and $\mathrm{FeSO}_{4} 7 \mathrm{H}_{2} \mathrm{O}, 0.01$. All salts were of analytical grade and were purchased from Acros Organics. The medium was adjusted to $\mathrm{pH} 9.0$ using $\mathrm{NaOH}$ solution. Cultivation was conducted in $5 \mathrm{~L}$ Erlenmeyer flasks. Cultures were maintained at $26 \pm 1{ }^{\circ} \mathrm{C}$ under air bubbling and continuously exposed to fluorescent lamps ( $100 \mu \mathrm{mol}$ photon $/ \mathrm{m}^{2} \mathrm{~s}$ ). After, the biomass was recovered by filtration, washed with physiological water for the removal of nutrient salts, and then dried at $40{ }^{\circ} \mathrm{C}$ for $48 \mathrm{~h}$. Then, it was lyophilized and the resulting powder was protected from moisture by storage in a closed vessel at $4{ }^{\circ} \mathrm{C}$. The Spirulina was dissolved in HEPES and it was filtered $(0.8 \mu \mathrm{m})$ before analysis. As Spirulina is made of transparent cells stacked end to end and entrapped with a sheath forming a spiral filament, the sheath was broken through filtration in order to separate individual cells. This step was very crucial for our studies.

\section{Love wave delay lines}

The Love wave sensor, resulting from previous studies [42], is an electromechanical sensor based on a SAW (surface acoustic wave) delay line with metalized interdigital transducers (IDT) to generate and receive an acoustic wave on a piezoelectric substrate (Fig. 1a). It consisted of a dual delay line deposited on AT cut quartz substrate (Euler angles: $0^{\circ}, 121.5^{\circ}$, and $90^{\circ}$ ) used as the piezoelectric material. IDTs were made by sputtering $70 \mathrm{~nm}$ of gold on top of a $30 \mathrm{~nm}$ titanium adhesion layer to achieve a good surface adhesion (Fig. 1a). Each IDT was composed of 44 split pairs of electrodes with a $40 \mu \mathrm{m}$ periodicity which defined the wavelength $\lambda$. Each electrode was $5 \mu \mathrm{m}$ wide with an aperture $w$ of $40 \lambda$, while the center to center path length between electroacoustic transducers $\left(L_{\mathrm{cc}}\right)$ was equal to $209 \lambda$. A $4 \mu \mathrm{m}$ plasma enhanced chemical vapor deposited (PECVD) $\mathrm{SiO}_{2}$ layer was used as the guiding layer. It generated a guided shear horizontal surface acoustic wave (guided SH SAW), also called Love wave. This confinement of the wave energy near the surface maximized the sensor sensitivity. It also ensured mechanical isolation of electrodes from biological samples. These character istics led to a $117 \mathrm{MHz}$ synchronous frequency $f_{0}$.

The obtained Love wave delay lines were inserted into an oscillation loop. Physicochemical perturbation onto the sensor surface will alter the wave velocity, which can be measured with high accuracy through the frequency shifts of the oscillation loop of a radio frequency amplifier. This leads to the achievement of an oscillator with ultra high stability, which had a considerable impact on the detection threshold of the Love wave sensor. This oscillator reached a short term stability lower than $1 \mathrm{~Hz} / \mathrm{s}$ at working frequencies higher than $100 \mathrm{MHz}$. The resonant frequency 


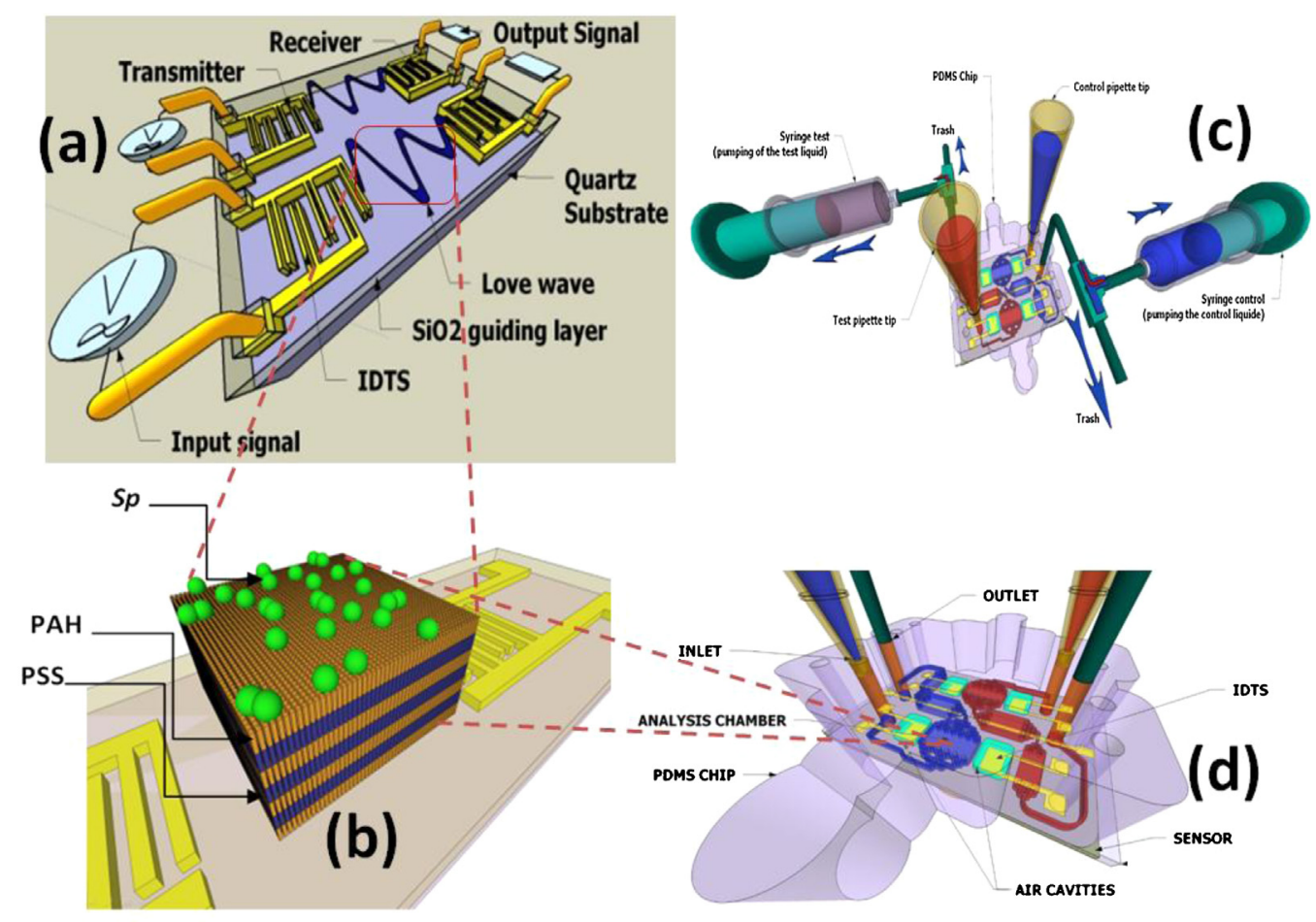

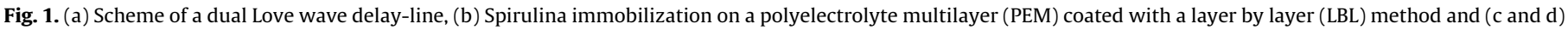
hydrodynamic chip with microfluidic network, aligned on a dual Love wave delay-line.

of the oscillator was measured with a 12 bit frequency counter (Agilent 53131A).

The microfluidic chips with integrated micro channels (Fig. 1c and d) were fabricated by standard soft photolithography methods, together with micromachining for external 3D shapes [43]. This process implies a two steps process: (1) a classic SU 8 resin negative mold on a silicon substrate for the microchannels; (2) this negative mold was inserted in a micromachined aluminum mold that defines the outside shape of the final microfluidic chips. This feature was of great interest, as the microfluidic chips were not irreversibly bonded on the sensor surface, but held in place by mechanical pressure, hence the need for precisely calibrated PDMS chips.

The SU 8 negative mold was obtained by spin coating SU 82100 on a silicon substrate using adequate process parameters to obtain a $200 \mu \mathrm{m}$ thick layer. This SU 8 negative mold was then inserted in our micromachined aluminum injection mold, where the mixture of PDMS was injected using a syringe pump after degassing. The PDMS was then cured for $20 \mathrm{~min}$ at $95{ }^{\circ} \mathrm{C}$ and the resulting chip with the microfluidic network pattern was peeled off from the mold.

For detection measurements, the sensor was inserted into a custom test cell, maintaining the PDMS chip with proper alignment and pressure on the Love wave device. The test cell provides connections and it was mounted in the retroaction path of a radio frequency amplifier. Fluid samples were flowed through the microchannels above the microsensor with a programmable syringe pump with $40 \mu \mathrm{L} / \mathrm{min}$ flow rate. Liquid samples were confined near the sensor surface and flowed along the acoustic path, on the main sensitive part of the microsensor and the analysis chambers were $2.6 \mu \mathrm{L}$ in volume.

Frequency variation was recorded after each deposit fluid. Mean values and error bars were calculated from 3 to 4 experiments with different delay lines.

\section{Electrochemical admittance spectroscopy}

Electrical measurements were performed in a conventional three electrode glass cell consisting of a working electrode of
$\mathrm{Si} / \mathrm{SiO}_{2}$, a platinum counter electrode, and $\mathrm{Ag} / \mathrm{AgCl}$ reference electrode. The working electrode was a heterostructure of $\mathrm{Si} /$ $\mathrm{SiO}_{2}$ divided into squares of $1 \mathrm{~cm}^{2}$; with silica obtained form thermal oxidation of a silicon wafer. The $\mathrm{p}$ type silicon has a ( $\left.\begin{array}{lll}1 & 0 & 0\end{array}\right)$ crystal orientation. The layer thickness of thermal silica was approximately $100 \mathrm{~nm}$. The ohmic contact was obtained with a layer of aluminum deposited on the back side. $\mathrm{Si} / \mathrm{SiO}_{2}$ electrodes were chosen for several reasons: the first one was due to its negative charge which promoted interactions with the first layer of polycations, in order to compare with Love wave results achieved on a sensor where its final layer was silica. The second reason is that the silica is a biocompatible material and $\mathrm{Si} / \mathrm{SiO}_{2}$ structures are compatible with microelec tronic technologies.

The electrochemical cell was designed to maintain a fixed distance between the electrodes. It was manufactured with two inlets: one for the positioning of the reference electrode and the other for heavy metal injections. This prevented further manipulation or movement of the electrodes. Fixing the geometry of the cell also ensured the reproducibility of measurements. The sensitive surface area of the working electrode was measured at $0.3 \mathrm{~cm}^{2}$. The electrochemical cell was placed in a Faraday cage and in measured in darkness while the solution was homogenized under magnetic stirring. Elec trochemical measurements were performed in TBS at $0.15 \mathrm{M}$. Impedance analysis was performed at $25^{\circ} \mathrm{C}$ by varying the frequency from $10 \mathrm{mHz}$ to $100 \mathrm{kHz}$ using a Metrohm Autolab 83139 impedance analyser controlled with FRA (frequency response analyser) software. An excitation voltage of $10 \mathrm{mV}$ was surimposed to a potential of $2300 \mathrm{mV}$ versus SCE. This potential attributes to the silicon accumulation range where the substrate behaved like a metal.

Impedance data was obtained for the bare and modified $\mathrm{Si} / \mathrm{SiO}_{2}$ electrodes and they were successfully modeled using the classical circuit ( $R$ and CPE (constant phase element in parallel)) [44] presented in Fig. 2c Electrical parameters were deduced from modeling by minimizing $\chi^{2}$ value. 

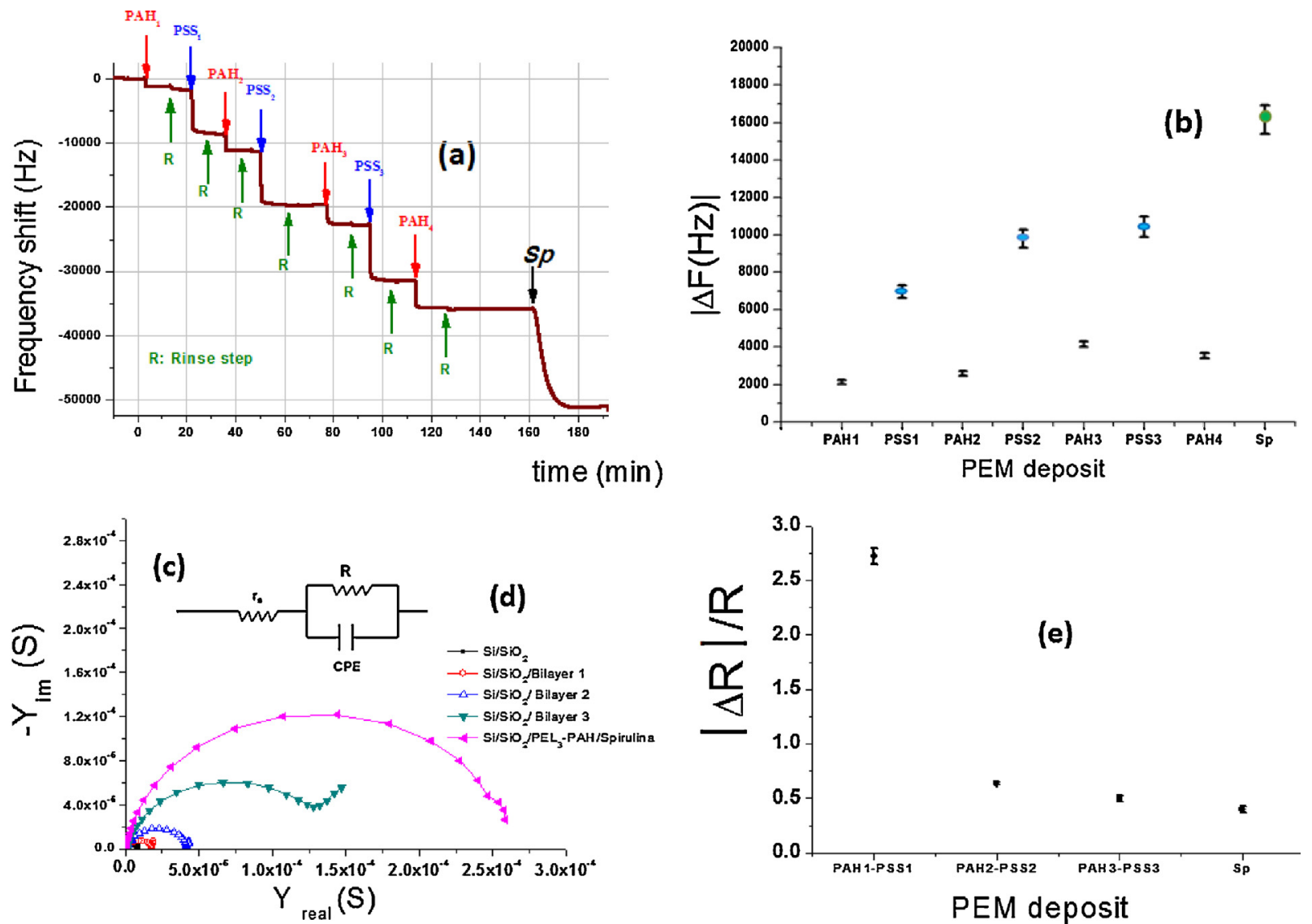

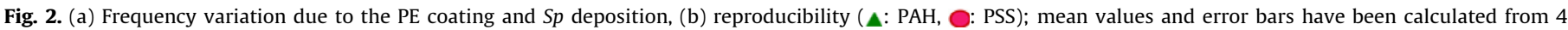

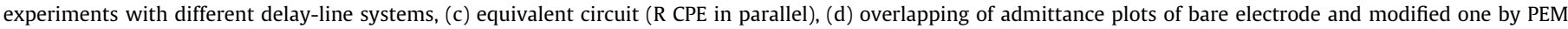

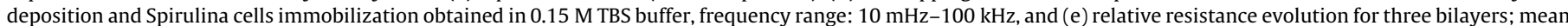
values and error bars have been calculated from 3 experiments.

The impedance of the $\mathrm{SiO}_{2} /$ electrolyte interface CPE can be expressed as:

$Z_{\mathrm{CPE}} \frac{1}{(Q j \omega)^{-n}}$

where $\omega$ is a circular frequency, $Q$ is a constant and $n$ is the parameter varies from 0 to 1 .

\section{AFM device}

AFM experiments were performed on the NSI platform of LOMA (Bordeaux 1) using a Bioscope II mounted on an Olympus inverted optical microscope and operated with a NanosCope $V$ controller (Veeco Brucker, Santa Barbara, CA). This AFM was equipped with a $G$ scanner (maximum $X Y Z$ scan range of $150 \mu \mathrm{m} \times 150 \mu \mathrm{m} \times 12 \mu \mathrm{m})$ [45]. In this work, samples were scanned in air and in the tapping mode using PPP NCL 50 silicon probes (NANOSENSORS ${ }^{\mathrm{TM}}$ ) with a spring constant of about $32 \mathrm{~N} /$ $\mathrm{m}$ and a corresponding measured resonance frequency of about $165 \mathrm{kHz}$. In contact mode, triangular SNL 10 silicon nitride probes (Veeco) with a nominal spring constant of $0.58 \mathrm{~N} / \mathrm{m}$ were used to probe Spirulina in liquid. All scans were measured with scan rates between 0.3 and $1 \mathrm{~Hz}$ (according to the scan size and the scanning mode). AFM data were processed using the Nanoscope version 7.30 (Veeco). For each experiment, six images were recorded at the same time: height images (trace and retrace), deflection images or signal error (trace and retrace) and friction images in contact (trace and retrace) or phase images in tapping (trace and retrace). For more clarity, images were flattened and only the trace height image was shown in this paper. Force curves were obtained with the same cantilever in the force calibration mode and collected by measuring the cantilever deflection as the sample was moved toward the tip [46,47]. In general, in the case of an AFM study of a given physico chemical treatment of surface, we performed a comparative study of samples corresponding to different phases of the treatment. In this study and for each treatment a series of three samples: the bare sensor was characterized, the sensor functionalized with PEM and finally the whole biosensor (the functionalized sensor on which Spirulina cells were attached). These experimental force curves were obtained with the same cantilever (stiffness of about $0.58 \mathrm{~N} / \mathrm{m}$ ) and with a $Z$ scan velocity of $1.6 \mu \mathrm{m} / \mathrm{s}$.

\section{Scanning electronic microscopy (SEM)}

The SEM images were captured using a Quanta ${ }^{\mathrm{TM}} 250$ microscope (FEI). A pretreatment of cells was needed before imaging. Cells were fixed, with covalent links using glutaraldehyde solution (3\%) purchased from Sigma, specially purified for use as an electron microscopy fixative. Spirulina based biosensors were immersed in this solution for $45 \mathrm{~min}$. After that, dehydration series in successive absolute ethanol solutions were applied for $10 \mathrm{~min}$ using increased concentrations ( $20 \%, 40 \%, 60 \%, 80 \%, 100 \%$ ethanol).

\section{Immobilization of cyanobacteria on transducer surfaces}

PEM formation was carried out by the alternative deposition of previous two polyelectrolytes. This LBL assembly technique was 
based on the electrostatic adsorption of oppositely charged polymer chains. Each polyelectrolyte deposit step was followed by a rinsing step with TBS $(0.15 \mathrm{M})$. This adsorption procedure was repeated up to three complete bilayers and a half(PAH PSS $)_{3} \mathrm{PAH}$ (Fig. 1b). A homogeneous positively charged layer on the latter was then obtained since the Spirulina is overall negatively charged [48 50]. The number of bilayers was optimized to obtain the maximum shift of frequency when Spirulina cells were deposited on the sensor surface. After each polyelectrolyte coating step, the unfixed polyelectrolyte was removed by rinsing. Cyanobacteria cells were, then, immobilized by physical adsorp tion (Fig. 1b).

\section{Acoustic characterization}

It is commonly acknowledged that the principle of acoustic wave sensor detection is mainly caused by mechanical effects and in particular mass loading due to the transducer surface perturbation induced by material deposition. In Fig. 2a, it can be seen that the signal stabilized within only 2 min after each polyelectrolyte coating step. It was noted that the mass and the thickness of these films grow linearly with the number of deposited bilayers [51 54]. Consequently, as the polymers thickness increased, inducing a mass loading effect, a frequency decrease was recorded after each polyelectrolyte coating step (Fig. 2a).

Concerning Spirulina cells immobilization, in our previous study [55], an optimization of the same cyanobacteria biofunctio nalization on the sensor surface has been achieved, using three generations of PDMS chips already manufactured (employed for a static, millifluidic and microfluidic setups, respectively). The bioreceptor immobilization response time was greatly reduced to half using the microfluidic set up. The same microfluidic configuration was employed in this present work. Further to the Spirulina immobilization, a frequency variation of $16 \pm 3 \mathrm{kHz}$ was recorded (Fig. 2a and b).

\section{Electrochemical admittance spectroscopy characterization}

Complex admittance spectra were recorded after each deposi tion of bilayers of polyelectrolyte (PAH PSS) followed by immobi lization of Spirulina. An increase of the diameter of the semi circle of the Nyquist plot was recorded as the thickness of the biofilm increased (Fig. 2d). Resistance evolution for three bilayers is presented in Fig. 2e where mean values and error bars have been calculated from 3 experiments, determined by modeling. The decrease of the resistance value is certainly due the important increase of the film conductivity during PEM formation. This parameter may be expressed as:

$R \frac{e}{\gamma S}$

where $\gamma$ is the conductivity, $S$ is the electrode surface, and $e$ is the biofilm thickness.

The absence of several semicircles in Fig. 2d can be explained by the pseudo stratified polyelectrolyte multilayers structure. Each layer of polyelectrolyte interpenetrates an underlayer [56]. Conse quently, there will be no interface formation during successive layers of polyelectrolyte deposition. A higher resistance decrease was observed from the deposition of the first bilayer (Fig. 2e).
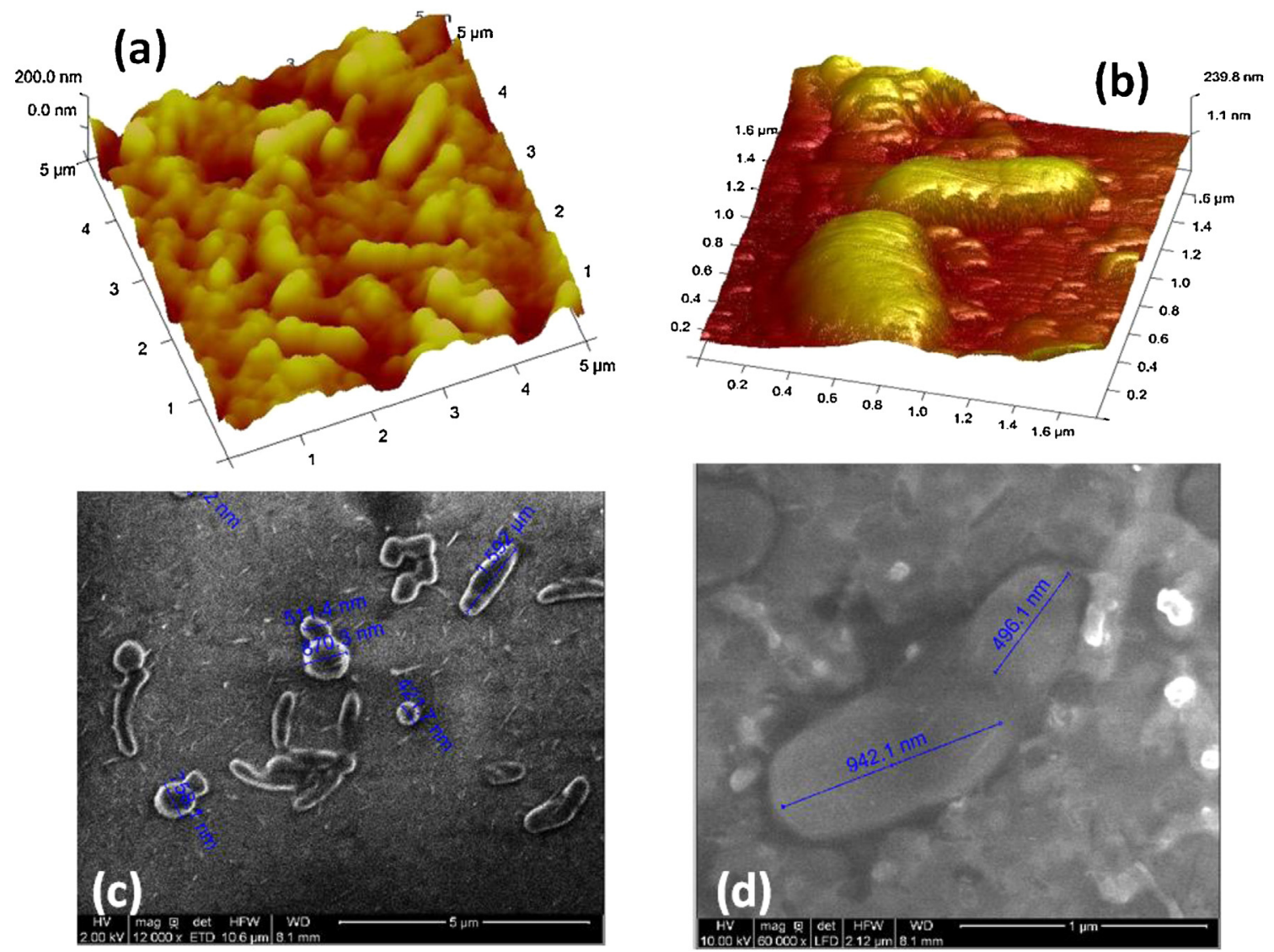

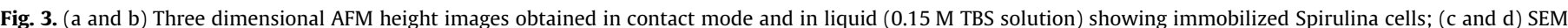

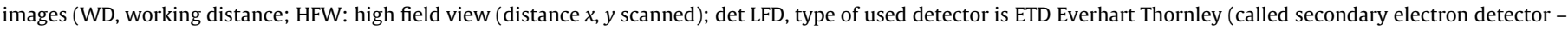
topographic contrast); mag: magnification value relatively to a polaroid format; HV: accelerating voltage). 

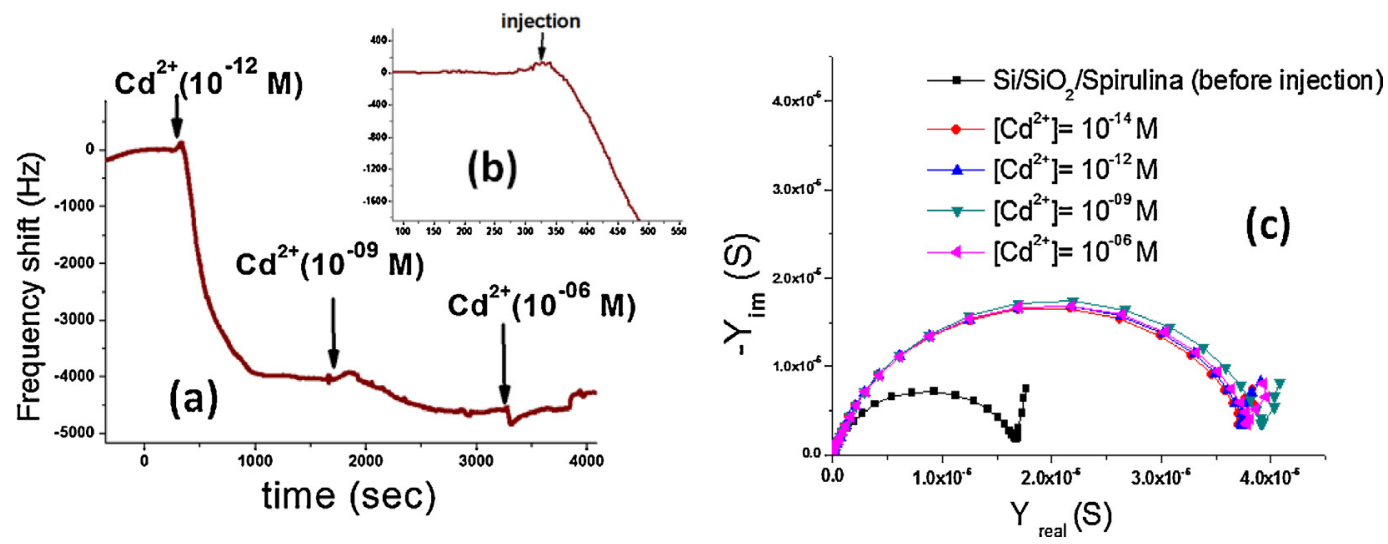

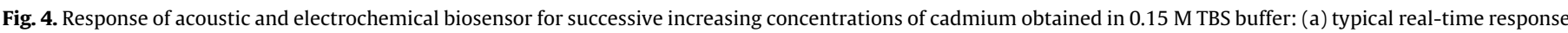

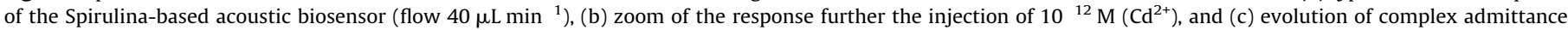
spectra of the $\mathrm{Si} / \mathrm{SiO}_{2} /$ biofilm structure, frequency range: $10 \mathrm{mHz}-100 \mathrm{kHz}$.

\section{Microscopic characterization}

AFM experiments performed on different areas of the electrode in liquid and contact mode revealed the coexistence of several populations: single cells whose average size was between 0.4 and $0.9 \mu \mathrm{m}$; while other cells were clustered in groups of two or three (Fig. 3a and b). Here, it was difficult to estimate individual cell dimensions. We can, however, give an order of magnitude of smaller cluster sizes which were of the order of $1.53 .5 \mu \mathrm{m}$ in length, $0.61 .5 \mu \mathrm{m}$ in width and $300400 \mathrm{~nm}$ in the height and the corresponding biovolume was about $0.42 .2 \mu \mathrm{m}^{3}$. Other manip ulations were performed on the same sample in air and in tapping mode; different dimensions were observed giving slightly lower cells volumes at about $0.11 \mu^{3}$. Once back in the liquid, Spirulina cells regained their shapes and their volumes and they remained stable after several scans of the surface.

SEM images in Fig. 3c and d presented also several populations of cells whose average size was between 0.4 and $0.9 \mu \mathrm{m}$.

\section{Heavy metal injection}

The following Love wave measurement protocol was applied: each Love wave platform comprised of two delay lines, one being used as the detection line with immobilized cells via PEM, while the other was used as a control line (based on PEM in the absence of Spirulina cells). This technique allowed differential measurement and limited external perturbations for e.g. temperature variations. Moreover, different kinetics (response time and initial response) could lead to further observations related to the Spirulina biofilm interactions for various heavy metals. After a complete stabiliza tion in TBS buffer following Spirulina immobilization, increasing concentrations of $\mathrm{Cd}^{2+}$ and $\mathrm{Hg}^{2+}$ in solution were injected in the range from $10{ }^{12} \mathrm{M}$ to $10{ }^{02} \mathrm{M}$.

Admittance variation was plotted for different concentrations of mercury and cadmium in solution, in contact with the Spirulina cells modified electrode. Increasing concentrations of heavy metals in solution, were injected in the range from $10{ }^{14} \mathrm{M}$ to $10{ }^{06} \mathrm{M}$. As a control, PEM response was studied toward metallic cation applying admittance spectroscopy.

\section{Results and discussion: interaction with heavy metal ions}

\section{Cadmium/biofilm interactions}

The typical real time response obtained through acoustic measurements with $\mathrm{Cd}^{2+}$ injection is presented in Fig. 4a and steady state frequency shifts are summarized in Fig. 5a. No frequency variation was observed on PEM based control line (in the absence of Spirulina cells). It can be seen, in Fig. 4b, that the real time frequency response decreases at the first injection of $\mathrm{Cd}^{2+}$ $\left(10{ }^{12} \mathrm{M}\right)$ and the induction time (time before detection of the initial response) was instantaneous and about $4 \mathrm{~s}$. The response time $\tau_{90 \%}$ of the biofilm toward $\mathrm{Cd}^{2+}$ was 8 min. A saturation phenomenon from $10^{09} \mathrm{M}$ was observed (Fig. 4a).
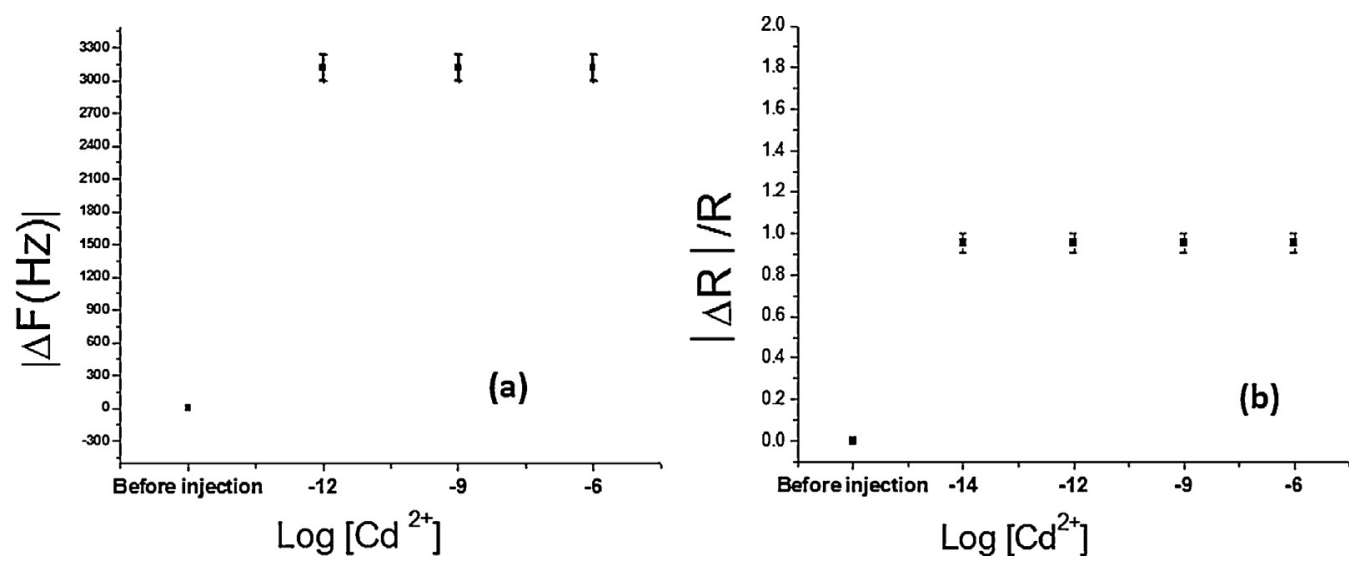

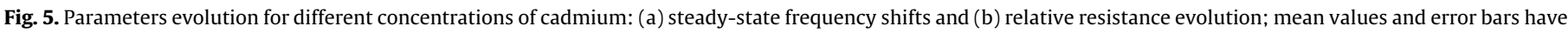
been calculated from 3 experiments with different electrodes. 

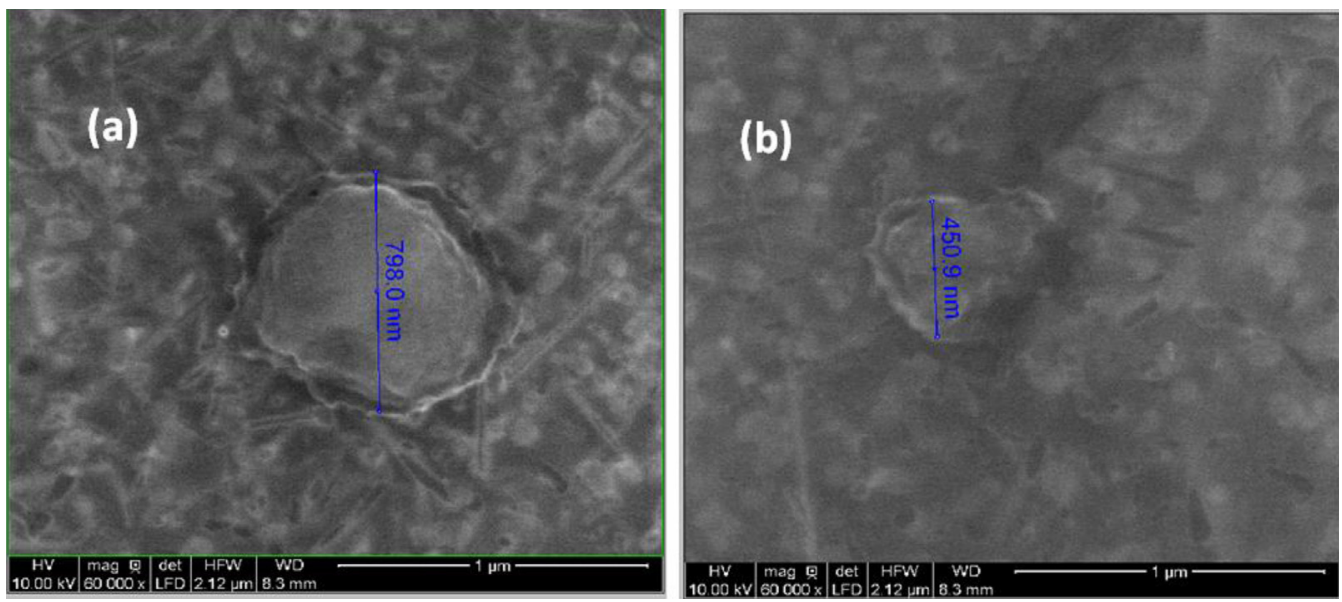

Fig. 6. SEM experiments on Spirulina cells after cadmium exposure: (a) $\mathrm{Cd}^{2+}\left(10{ }^{14} \mathrm{M}\right)$ and $(b) \mathrm{Cd}^{2+}\left(10{ }^{09} \mathrm{M}\right)$.

Admittance value evolution was observed in medium and high frequencies, with Spirulina based biofilm at the first injection of cadmium where the final concentration in the solution was about $10{ }^{14} \mathrm{M}$ (Fig. 4c). In fact, the increase of imaginary admittance $\left(Y_{\mathrm{im}}\right)$ and the shift of the real admittance position $\left(Y_{\text {real }}\right)$ were recorded. After modeling Nyquist plots using the equivalent circuit, a decrease of the resistance of the film was observed as well as an increase of the CPE (equivalent to capacitance). The relative variation of resistance $R$ versus concentration of cadmium concentration in contact is presented in Fig. 5b. A rapid saturation phenomenon was obtained at the second injection $10{ }^{12} \mathrm{M}\left(\mathrm{Cd}^{2+}\right)$ (Fig. 4c). This is in agreement with the real time response recorded with Love wave platform where the frequency decreases at the first injection of cadmium $\left(10^{12} \mathrm{M}\right)$ followed by a rapid saturation phenomena (Figs. 4a and 5a). SEM image presented in Fig. 6a reveals the effect of cadmium cations at $10{ }^{14} \mathrm{M}$ on Spirulina cells. Indeed, there are significant changes on the external surface and remarkable irregularities appeared on the outer cell wall such as on the second wall. It was found that the external surface of some bacteria develop a protective layer of excreted polymer, as a defense against cadmium by restricting the ion permeability into the cell [57 59]. This phenomenon can also explain that the response time for the substrate of alkaline phosphatase in Spirulina has been increased after exposure to cadmium and mercury [60].

According to Rangsayatorn et al., transmission electron micro graphs of Spirulina sections revealed the effects induced by cadmium: disintegration and disorganization of thylakoid mem branes, presence of large intrathylakoidal space, reduction of gas vacuoles and an increase of polyphosphate bodies (PPBs). [13]. Ruiz et al. demonstrated using $X$ ray microanalysis of the electron dense vacuoles or polyphosphate bodies of Chlamydomonas reinhardtii [61] that there were large amounts of phosphorus, magnesium, calcium and zinc. The increase of PPBs, in presence of cadmium could explain the observed decrease of resistance; the subsequent reduction of gas vacuoles could lead to an increase of density and of the dielectric constant, and thus connected to an increase of capacitance of the Spirulina film from $1.34 \times 10^{8} \mathrm{~F}$ without cadmium to $1.37 \times 10^{8} \mathrm{~F}$ for $\left[\mathrm{Cd}^{2+}\right]$ equal to $10^{6} \mathrm{M}$. The observed decrease of the frequency, $4 \mathrm{~s}$ after injection $(3100 \mathrm{~Hz}$ as a mean value (Fig. 5a)) could be attributed to the increase of density. SEM experiments performed on Spirulina exposed to a concentration of $10{ }^{09} \mathrm{M}$ of cadmium, shows the beginning of cell lysis and a decrease of their diameter (Fig. 7b).
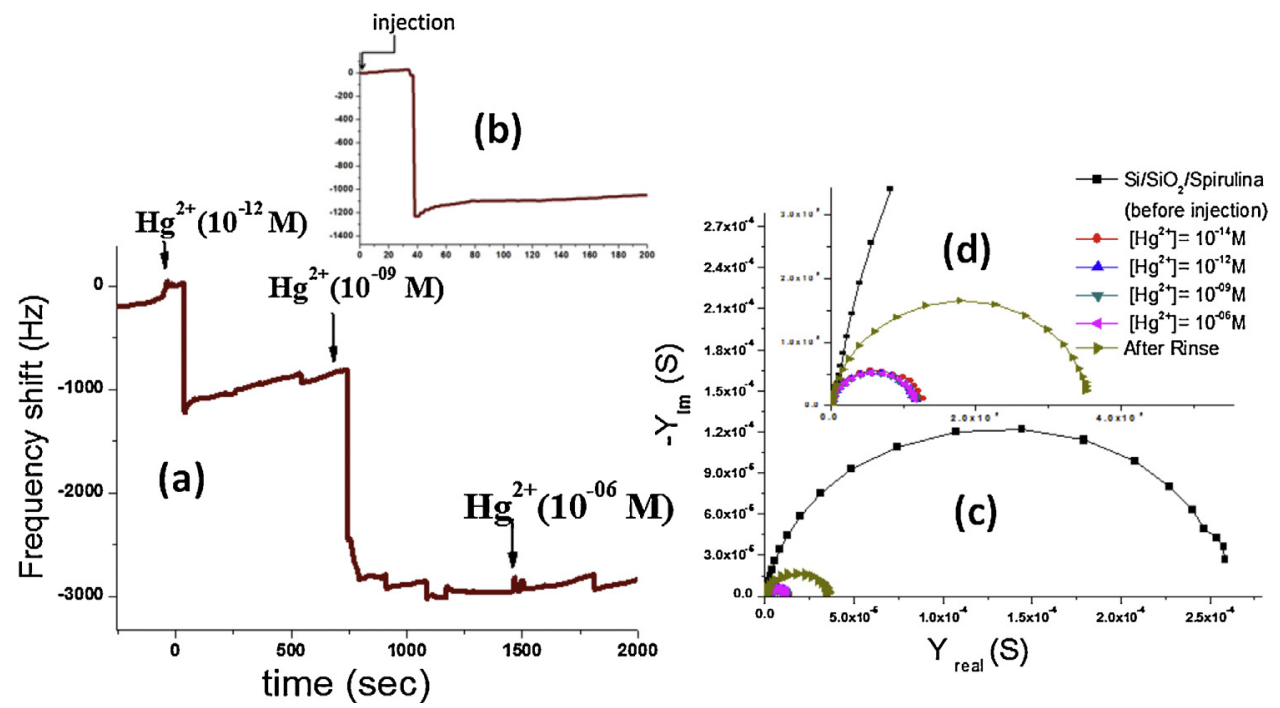

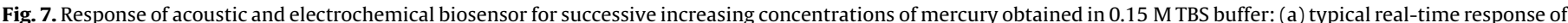

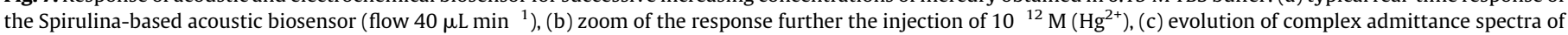
the $\mathrm{Si} / \mathrm{SiO}_{2} /$ biofilm structure, frequency range: $10 \mathrm{mHz}-100 \mathrm{kHz}$ and (d) enlarged curves. 

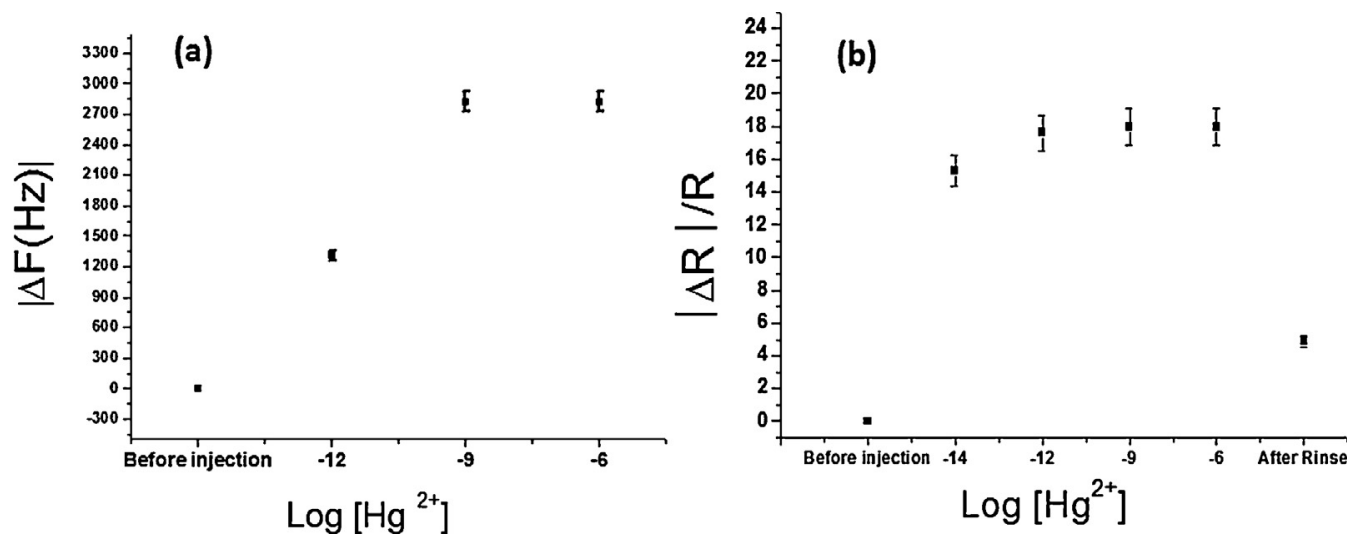

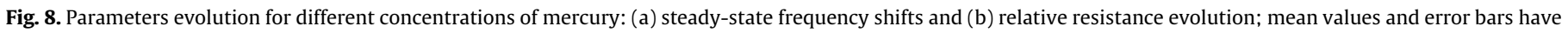
been calculated from 3 experiments with different electrodes.

\section{Mercury/biofilm interactions}

A control measurement was performed with the PEM without Spirulina to show that no variation of admittance could be observed when adding $\mathrm{Hg}^{2+}$. In presence of cyanobacteria cells and following successive injections of mercury, a decrease of the imaginary admittance was recorded (Fig. 7c and d). After modeling the Nyquist plots using the equivalent circuit, an increase of the resistance of the film was observed as well as a decrease of the CPE (equivalent to a capacitance). The relative increase of the resistance $(\Delta R / R)$ is presented in Fig. 8b. It varies between 15 and 18, in comparison with the control measurement recorded with PEM, where the relative variation of resistance $(\Delta R / R)$ did not exceed 0.17 , calculated from the modeled spectra for $10{ }^{06} \mathrm{M}$ of $\mathrm{Hg}^{2+}$.

At the second injection of mercury $\left(10{ }^{12} \mathrm{M}\right)$, a small variation of the resistance value was recorded (Fig. 8b) and a saturation phenomenon was observed just after. These observations were, also, in agreement with the frequency shifts recorded in real time at $10{ }^{12} \mathrm{M}$ and $10{ }^{09} \mathrm{M}$ of mercury using the Love wave platform (Fig. 7a and b): detection of mercury at the first $\left(10^{12} \mathrm{M}\right)$ and at the second $\left(10^{09} \mathrm{M}\right)$ injections, followed by a saturation phenomena. Induction time of mercury was about $40 \mathrm{~s}$ after the first injection ( $10^{12} \mathrm{M}$ ) and the response time $\tau_{90 \%}$ of the biofilm did not exceed few second (Fig. 7b).

Cogne et al. [62] studied $\mathrm{Zn}, \mathrm{Mg}, \mathrm{Fe}, \mathrm{Mn}, \mathrm{Cu}, \mathrm{K}$, uptake by Spirulina in general, and they reported that microorganism metal interaction consisted in physical adsorption and chemical absorption. The partial reversibility of the admittance noticed after a rinsing step can then eliminate cations physically fixed on the cell wall (Fig. 7c).

SEM images were achieved in the same conditions and performed on Spirulina cells exposed to the same concentration $\left(10{ }^{14} \mathrm{M}\right)$ of mercury. There was a clear modification of the total cell morphology expressed by depressions and holes (Fig. 9a).

Generally, the uptake of metal ions by microorganisms has been reported in two stages [63,64]: an initial, rapid stage and a later, slower stage. In the first stage, which is called the rapid phase, the metal ions are fixed onto the surface of microorganisms. This very fast uptake in the cell envelope was confirmed in [57]. According to Wang and Chen [65], there is stoichiometric interaction between functional groups of cell wall composition, including phosphate, carboxyl, amine as well as phosphodiester. In the second stage, a longer uptake period inside the cell takes place [57]. The metal ions are transported across the cell membrane into the cytoplasm [63]. Also, according to Wang and Chen [65], there is a physicochemical inorganic deposition via adsorption or inorganic precipitation in this second stage.

In addition, Lefebvre et al. [66] studied the biotransformation of $\mathrm{Hg}$ (II) by cyanobacteria. They revealed that meta cinnabar (beta $\mathrm{HgS}$ ) constituted the major biotransformed and cellularly associ ated mercury pool. In the presence of mercury, there was a rapid synthesis of beta $\mathrm{HgS}$ and $\mathrm{Hg}(0)$, however, the production rate for the latter decreased quickly. Consequently, cyanobacteria could act to convert substantial amounts of $\mathrm{Hg}$ (II) into beta $\mathrm{HgS}$. Kaoud
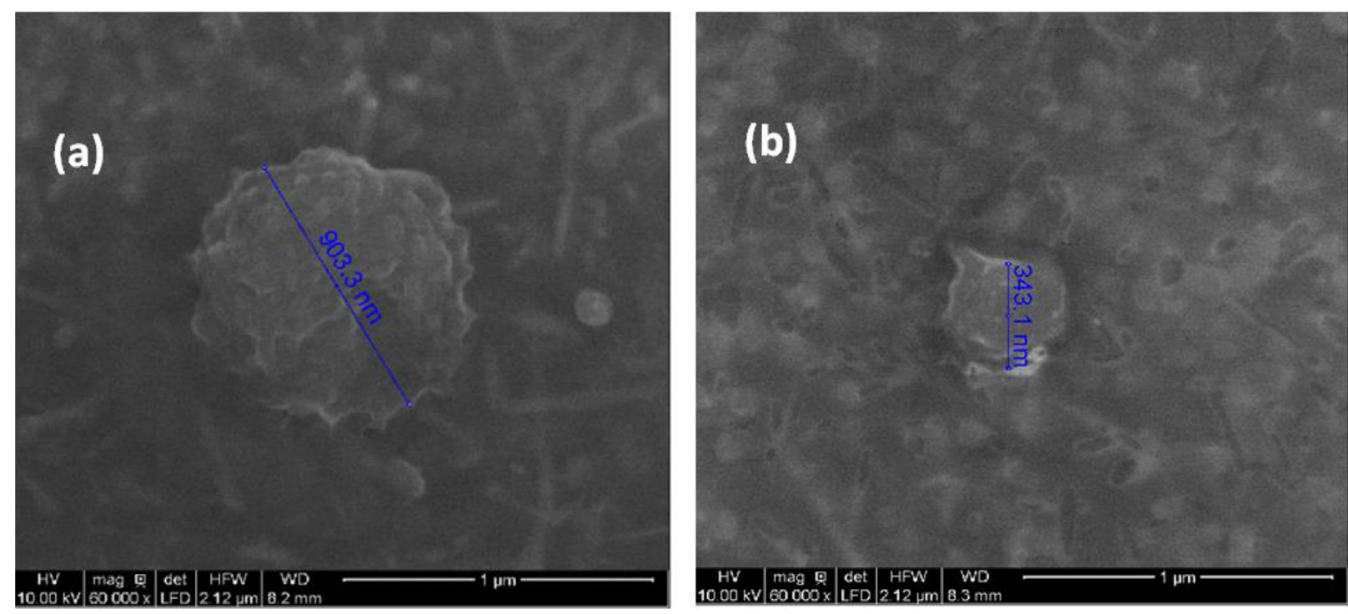

Fig. 9. SEM experiments on Spirulina cells after mercury exposure: (a) $\mathrm{Hg}^{2+}\left(10{ }^{14} \mathrm{M}\right),(\mathrm{b}) \mathrm{Hg}^{2+}\left(10{ }^{09} \mathrm{M}\right)$. 

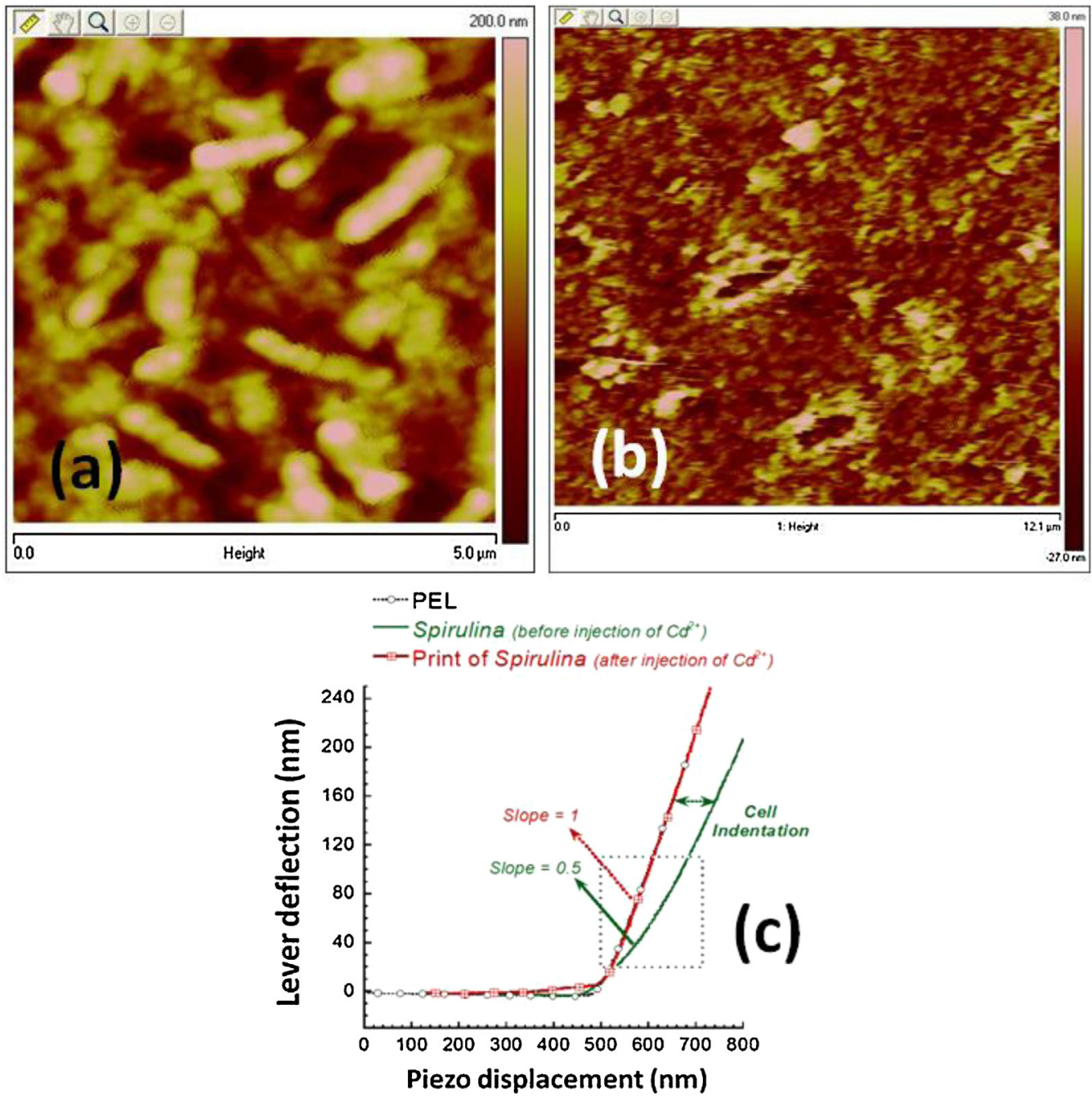

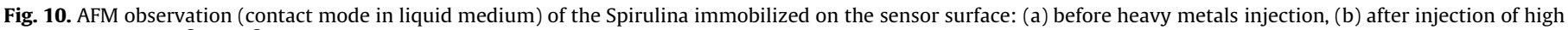

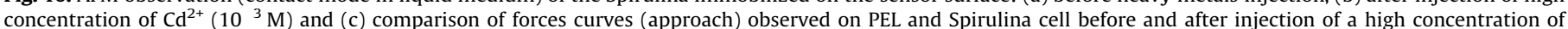
cadmium.

et al. [67] suggest that Spirulina platensis could chelate $\mathrm{Hg}$ ions producing a stable complex.

Based on these studies, we can conclude that mercury cations can penetrate directly into Spirulina cell. The initial rapid phase of mercury uptake took $40 \mathrm{~s}$ to reach the saturation stage (induction time). Once external sorption reached the saturation stage, internal uptake began [58], cations were transported across the cell membrane into the cytoplasm and a beta $\mathrm{HgS}$ synthesis took place [65]. This chemical compound, precipitated as a black powder, is insoluble in water, stable and had a crystal structure. Therefore, mercury sulfide precipitation may decrease the biofilm conductivity, which is in agreement with the strong increase of the resistance value observed in presence of mercury cations (Fig. 8b). The observed decrease of capacitance of the Spirulina film (from $1.41 \times 10^{8} \mathrm{~F}$ without mercury to $1.25 \times 10^{8} \mathrm{~F}$ for $\left[\mathrm{Hg}^{2+}\right]$ equal to $10{ }^{6} \mathrm{M}$ ) could also be in agreement with the formation of mercury sulphide whose dielectric constant is about 25 , and is lower than that of the Spirulina cell equal to 40 [68]. The formation of mercury sulfide precipitation generates an increase of density, and so a decrease of frequency in real time (Fig. 7a) with a mean value of about $2700 \mathrm{~Hz}$ accumulated after two successive injections of mercury $\left(10^{12} \mathrm{M}\right.$ and $10^{09} \mathrm{M}$ ) (Fig. 8a).
Biofilm exposed to high concentrations of $\mathrm{Cd}^{2+}$ and $\mathrm{Hg}^{2+}$

Above $10{ }^{03} \mathrm{M}$ of cadmium and mercury, complete lysis of the Spirulina cells was observed by the AFM characterization in liquid medium (contact mode). Indeed, it can be seen from the comparison between Fig. 10a and b, a disappearance of Spirulina cells, resulting in tracks, surrounded by the cell material, was also in agreement with the force curves presented in Fig. 10c. Similarly, comparing the force curves performed on cells (before injection of $\left(\mathrm{d}^{2+}\right.$ ) and those performed on the prints of Spirulina cells, confirmed those results. In fact, following the injection of a very high concentration of $\mathrm{Cd}^{2+}\left(>10{ }^{3} \mathrm{M}\right)$, the modulus identified on the prints was the same as those identified on the initial substrate (PEM) accrediting Spirulina cells degradation. This observed bursting of the cells is in agreement with transmission electron micrographs observations of a Spirulina section reported in Rangsayatorn et al. [13], revealing Spirulina cell lysis induced by cadmium exposure.

\section{Conclusion}

Immobilization of Spirulina cells was carried out successfully via multilayers of polyelectrolytes. Analysis of the acoustic 
response, associated to admittance spectroscopy and characteri zation of surface using AFM and SEM, allowed to propose and to verify some physico chemical mechanisms involved in the interaction between lyophilized biomass of Spirulina cells and heavy metals. Biofilm interaction mechanisms, analyzed toward cadmium and mercury were totally different and a detection limit was determined to be $10{ }^{14} \mathrm{M}$ for each metal. That bioreceptor response is sensitive enough to provide preliminary in situ environmental analysis. This biosensor is not specific for a single metal, but it provides a global response of the presence of heavy metals in trace. Such rapid and non destructive measurements could be applied with other micro organisms for achieving toxicity tests.

\section{Acknowledgments}

This work was financially supported by the CMCU, project No. 10G1103. PDMS chips were designed in the frame of ANR project BIOALERT. Authors would like to thank Michael Lee for the English revision.

\section{References}

[1] S.K. Mehta, J.P. Gaur, Use of algae for removing heavy metals ions from wastewater: progress and prospects, Journal of Critical Reviews in Biotechnology 25 (2005) $113-152$.

[2] R. Apiratikul, P. Pavasant, Bach and column studies of biosorption of heavy metals by Caulerpa lentillifera, Journal of Bioresource Technology 99 (2008) 2766-2777.

[3] Y.P. Kumar, P. King, V.S.R.K. Prasad, Equilibrium and kinetic studies for the biosorption system of copper(II) ion from aqueous solution using Tectona grandis L.f. leaves powder, Journal of Hazardous Materials 137 (2006) 1211-1217.

[4] C. Cojocaru, M. Diaconu, I. Cretescu, J. Savic, V. Vasic, Biosorption of copper(II) ions from aqua solutions using dried yeast biomass, Journal of Colloids and Surfaces A 335 (2009) 181-188.

[5] Official Journal of the European Union 331 (2001) 1-5.

[6] Official Journal of the European Union, L81 ed., JOL, vol. 2008/32/CE (2008) 60-61.

[7] A. Sbartai, P. Namour, A. Errachid, J. Krejci, R. Sejnohova, L. Renaud, M.L. Hamlaoui, A.S. Loir, F. Garrelie, C. Donnet, H. Soder, E. Audouard, J. Granier, N. JaffrezicRenault, Electrochemical boron-doped diamond film microcells micromachined with femtosecond laser: application to the determination of water framework directive metals, Journal of Analytical Chemistry 84 (2012) 4805-4811. , http:// dx.doi.org/10.1021/ac3003598.

[8] I. Gammoudi, H. Tarbague, J.L. Lachaud, S. Destor, A. Othmane, et al., Love wave bacterial biosensors and microfluidic network for detection of heavy metal toxicity, Journal of Sensor Letters 9 (2) (2011) 816-819.

[9] C. Durrieu, C. Tran-Minh, Optical algal biosensor using alkaline phosphatase for determination of heavy metals, Journal of Ecotoxicology and Environmental Safety 51 (3) (2002) 206-209.

[10] P. Pandard, P. Vasseur, D.M. Rawson, Comparison of two types of sensors using eukaryotic algae to monitor pollution of aquatic systems, Journal of Water Research 27 (3) (1993) 427-431.

[11] C. Chouteau, S. Dzyadevych, C. Durrieu, J-M. Chovelon, A bi-enzymatic whole cell conductometric biosensor for heavy metal ions and pesticides detection in water samples, Journal of Biosensors \& Bioelectronics 21 (2005) 273-281.

[12] H. Guedri, C. Durrieu, A self-assembled monolayers based conductometric algal whole cell biosensor for water monitoring, Journal of Microchimica Acta 163 (2008) 179-184. , http://dx.doi.org/10.1007/s00604-008-0017-2.

[13] N. Rangsayatorn, E.S. Upatham, M. Kruatrachue, P. Pokethitiyook, G.R. Lanza, Phytoremediation potential of Spirulina (Arthropira) platensis: biosorption and toxicity studies of cadmium, Journal of Environmental Pollution 119 (2002) 45-53.

[14] L. Fang, C. Zhou, P. Cai, W. Chen, X. Rong, et al., Binding characteristics of copper and cadmium by cyanobacterium Spirulina platensis, 2011, Journal of Hazardous Materials 190 (1-3) (2011) 810-815.

[15] Z.Y. Li, S.Y. Guo, L. Li, Study on the process, thermodynamical isotherm and mechanism of $\mathrm{Cr}$ (III) uptake by Spirulina platensis, Journal of Food Engineering 75 (2006) 9-136. , http://dx.doi.org/10.1016/j.jfoodeng.2005.04.003.

[16] A. Şeker, T. Shahwan, A.E. Eroğlu, S. Yılmaz, Z. Demirel, M. Conk Dalay, Equilibrium, thermodynamic and kinetic studies for the biosorption of aqueous lead(II), cadmium(II) and nickel(II) ions on Spirulina platensis, Journal of Hazardous Materials 154 (1-3) (2008) 973-980.

[17] S. Schiewer, M.H. Wong, Ionic strength effects in biosorption of metals by marine algae, Chemosphere 41 (2000) 271-282.

[18] Z. Aksu, Determination of the equilibrium, kinetic and thermodynamic parameters of the batch biosorption of nickel(II) ions onto Chlorella vulgaris, Process Biochemistry 38 (2002) 89-99.

[19] S. Markai, Y. Andres, G. Montavon, B. Gram bow, Study of the interaction between europium(III) and Bacillus subtilis: fixation sites, biosorption modelling and reversibility, Journal of Colloid and Interface Science 262 (2003) 351-361.
[20] A. Vonshak (Ed.), Spirulina platensis (Arthrospira) Physiology, Cell-biology and Biotechnology, Taylor \& Francis, London, 1997.

[21] A.B. Ari, M. Mel, M.A. Hasan, M.I.A. Karim, The kinetics and mechanism of lead(II) biosorption by powderized Rhizopus oligosporus, World Journal of Microbiology and Biotechnology 15 (1999) 291-298.

[22] D. Roy, P.N. Greenlaw, B.S. Shane, Adsorption of heavy metals by green algae and ground rice hulls, Journal of Environmental Science and Health 28 (1993) 37-50.

[23] J.R. MacDonald, Impedance Spectroscopy Emphasizing Solid Materials and Systems, Wiley, New York, 1987.

[24] M.I. Newton, G. McHale, F. Martin, Experimental study of Love wave devices with thick guiding layers, Journal of Sensors and Actuators A: Physical 109 (3) (2003) 180-185.

[25] A. Simon, T. Cohen-Bouhacina, M.C. Porté, J.P. Aimé, J. Amédée, R. Bareille, C. Baquey, Characterization of dynamic cellular adhesion of osteoblasts using atomic force microscopy, Cytometry Part A 54 (1) (2003) 36-47. , http:// dx.doi.org/10.1002/cyto.a.10052.

[26] P. Jianhua, G. Xiaopeng, L. Ruixia, T. Hongxiao, Characteristic features of Bacillus cereus cell surfaces with biosorption of $\mathrm{Pb}(\mathrm{II})$ ions by AFM and FT-IR, Colloid Surface B: Biointerfaces 52 (2006) 89-95. , http://dx.doi.org/10.1016/j.colsurfb.2006.05.016.

[27] G.W. Schmid-Schonbein, K.L. Sung, H. Tozeren, R. Skalak, S. Chien, Passive mechanical properties of human leukocytes, Biophysics 36 (1981) 243-256.

[28] R. Tran-Son-Tay, D. Needham, A. Yeung, R.M. Hochmuth, Time-dependent recovery of passive neutrophils after large deformation, Biophysics 60 (1991) 856-866.

[29] M. Radmacher, R.W. Tillmann, M. Fritz, H.E. Gaub, From molecules to cells: imaging soft samples with the atomic force microscope, Science 257 (1992) 1900-1905.

[30] R.M. Hochmuth, H.P. Ting-Beall, B.B. Beaty, D. Needham, R. Tran-Son-Tay, Viscosity of passive human neutrophils undergoing small deformations, Biophysics 64 (5) (1993) 1596-1601

[31] M. Bezanilla, B. Drake, E. Nudler, M. Kashlev, P.K. Hansma, H.G. Hansma, Motion and enzymatic degradation of DNA in the atomic force microscope, Biophysics 67 (6) (1994) 2454-2459.

[32] S. Kasas, N.H. Thomson, B.L. Smith, H.G. Hansma, X. Zhu, M. Guthold, C. Bustamante, E.T. Kool, M. Kashlev, P.K. Hansma, Escherichia coli RNA polymerase activity observed using atomic force microscopy, Biochemistry 36 (3) (1997) 461-468.

[33] D.J. Müller, A. Engel, The height of biomolecules measured with the atomic force microscope depends on electrostatic interactions, Biophysics 73 (3) (1997) 1633-1644.

[34] D.J. Müller, A. Engel, Voltage and pH-induced channel closure of porin OmpF visualized by atomic force microscopy, Journal of Molecular Biology 285 (4) (1999) 1347-1351.

[35] L.S. Shlyakhtenko, V.N. Potaman, R.R. Sinden, Y.L. Lyubchenko, Structure and dynamics of supercoil-stabilized DNA cruciforms, Journal of Molecular Biology 280 (1) (1998) 61-72.

[36] A. Engel, Y. Lyubchenko, D. Müller, Atomic force microscopy: a powerful tool to observe biomolecules at work, Trends in Cell Biology 9 (2) (1999) 77-80.

[37] M. Radmacher, J.P. Cleveland, M. Fritz, H.G. Hansma, P.K. Hansma, Mapping interaction forces with the atomic force microscope, Biophysics 66 (6) (1994) 2159-2165.

[38] M. Radmacher, M. Fritz, H.G. Hansma, P.K. Hansma, Direct observation of enzyme activity with the atomic force microscope, Science 265 (5178) (1994) 1577-1579.

[39] M. Schonhoff, Self-assembled polyelectrolyte multilayers, Journal of Current Opinion in Colloid and Interface Science 8 (2003) 86-95.

[40] G. Decher, J.B. Schlenoff, Multilayer Thin Films-Sequential Assembly of Nanocomposite Materials, Wiley-VCH, Weinheim, 2003.

[41] H. Zhu, J. Ji, J. Shen, Biomacromolecules electrostatic self-assembly on 3-dimensional tissue engineering scaffold, Journal of Biomacromolecules 5 (2004) 1933-1939.

[42] N. Moll, E. Pascal, H-D. Duy, J.-P. Pillot, B. Bennetau, D. Rebière, D. Moynet, Y. Mas, D. Moissalayi, J. Pistré, C. Dejous, A Love wave immunosensor for whole E. coli bacteria detection using an innovative two-step immobilisation approach, Journal of Biosensors \& Bioelectronics 22 (9-10) (2007) 2145-2150.

[43] H. Tarbague, J.L. Lachaud, S. Destor, L. Vellutini, J.P. Pillot, PDMS (polydimethylsiloxane) microfluidic chip molding for Love wave biosensor, Journal of Integrated Circuits and Systems 5 (2) (2010) 125-133.

[44] J.R. MacDonald, D.R. Fransceschetti, Physical and electrochemical models, in: J.R. MacDonald (Ed.), Impedance Spectroscopy Emphasizing Solid Materials and Systems, Wiley, New York, 1987, p. 84.

[45] Digital Instruments, Santa Barbara, CA

[46] J.P. Aimé, Z. Elkaakour, C. Odin, T. Bouhacina, T. Michel, J. Curély, A. Dautant, Comments on the use of the force mode in atomic force microscopy for polymer films, Journal of Applied Physics 76 (1994) 754-762.

[47] A. Simon, T. Cohen-Bouhacina, M.C. Porté, J.P. Aimé, J. Amédée, R. Bareille, C. Baquey, Characterization of dynamic cellular adhesion of osteoblasts using atomic force microscopy, Cytometry Part A 54 (2003) 36-47.

[48] D. Thomas, V. Bohumil, M. Alfonso, A review of the biochemistry of heavy metal biosorption by brown algae, Water Research 37 (2003) 4311-4330.

[49] H.B. Xue, W. Stumm, L. Sigg, The binding of heavy metals to algal surfaces, Water Research 22 (1988) 917-926.

[50] N. Tekaya, N. Sakly, H. Ben Ouada, H. Ben Ouada, N. Jaffrezic-Renault, F. Lagarde, Impedimetric characterization of alginate entrapped Arthrospira platensis at a platinum/electrolyte interface. effect of cadmium ions, Journal of Sensor Letters 9 (2011) 1-5. 
[51] F. Caruso, K. Niikura, D.N. Furlong, Y. Okahata, Assembly of alternating polyelectrolyte and protein multilayer films for immunosensing, Langmuir 13 (1997) 3422-3426.

[52] J. Ruths, F. Essler, G. Decher, H. Riegler, Polyelectrolytes I: polyanion/polycation multilayers at the air/monolayer/water interface as elements for quantitative polymer adsorption studies and preparation of hetero-superlattices on solid surfaces, Langmuir 16 (2000) 8871-8878.

[53] J.J. Ramsden, Y.M. Lvov, G. Decher, Determination of optical constants of molecular films assembled via alternate polyion adsorption, Thin Solid Films 254(1995)246-251.

[54] C. Picart, P. Lavalle, P. Hubert, F.J.G. Cuisinier, P. Decher, P. Schaaf, J.C. Voegel, Buildup mechanism for poly(L-lysine)/hyaluronic acid films onto a solid surface Langmuir 17 (2001) 7414-7424.

[55] N. Tekaya, H. Tarbague, F. Morote, I. Gammoudi, N. Sakly, H. Ben ouada, V. Raimbault, D. Rebiere, H. Ben Ouada, N. Jaffrezic-Renault, F. Lagarde, C. Dejous, T. Cohen-Bouhacina, Optimization of Spirulina biofilm for in-situ heavy metals detection with microfluidic-acoustic sensor and AFM, in: Proceeding in 14th International Meeting on Chemical Sensors (IMCS 2012), Nürnberg/Nuremberg, Germany, (2012), pp. 92-95. , http://dx.doi.org/10.5162/IMCS2012/1.2.5.

[56] M. Losche, J. Schmitt, G. Decher, W.G. Bouwman, K. Kjaer, Detailed of structure of molecularly thin polyelectrolyte multilayer films on solid substrates as revealed by neutron reflectometry, Macromolecules 31 (1998) 8893-8906.

[57] D.T. Swift, D. Forciniti, Accumulation of lead by Anabaena cylindrica: mathematical modeling and an energy dispersive X-ray study, Journal of Biotechnology and Bioengineering 55 (1997) 408-419.

[58] J.A. Scott, S.J. Palmer, Site of cadmium uptake in bacteria used for biosorption, Applied Microbiology and Biotechnology 33 (1990) 221-225.

[59] G. Bitton, V. Freihofer, Influence of extracellular polysaccharides on the toxicity of copper and cadmium towards Klebsiella aerogenes, Microbial Ecology 4 (1978) 119-125.
[60] N. Tekaya, O. Saiapina, H. Ben Ouada, F. Lagarde, H. Ben Ouada, N. JaffrezicRenault, Ultra-sensitive conductometric detection of heavy metals based on inhibition of alkaline phosphatase activity from Arthrospira platensis, Bioelectrochemistry 90 (2013) 4-29. , http://dx.doi.org/10.1016/j.bioelechem.2012.10.001.

[61] F.A. Ruiz, N. Marchesini, M. Seufferheld, R. Govindjee Docampo, The polyphosphate bodies of Chlamydomonas reinhardtii possess a proton-pumping pyrophosphatase and are similar to acidocalcisomes, Journal of Biological Chemistry 276 (2001) 46196-46203. , http://dx.doi.org/10.1074/jbc.M105268200.

[62] G. Cogne, B. Lehmann, C. Dussap, J. Gros, Uptake of macrominerals and trace elements by the cyanobacterium Spirulina platensis (Arthrospira platensis PCC 8005 ) under photoautotrophic conditions: culture medium optimization, Journal of Biotechnology and Bioengineering 81 (2003) 588-593.

[63] Y.P. Ting, F. Lawson, I.G. Prince, Uptake of cadmium and zinc by the alga Chlorella vulgaris: Part 1. Individual ion species, Journal of Biotechnology and Bioengineering 34 (1989) 990.

[64] S. Imani, S. Rezaei-Zarchi, M. Hashemi, H. Borna, A. Javid, A.M. Zand, H.B. Abarghouei, $\mathrm{Hg}, \mathrm{Cd}, \mathrm{Pb}$ heavy metal bioremediation by Dunaliella alga, Journal of Medicinal Plants Research 5 (13) (2011) 2775-2780

[65] J.L. Wang, C. Chen, Biosorption of heavy metals by Saccharomyces cerevisiae: a review, Biotechnology Advances 24 (5) (2006) 427-451. , http://dx.doi.org/ 10.1016/j.biotechadv.2006.03.001.

[66] D.D. Lefebvre, D. Kelly, K. Budd, Biotransformation of $\mathrm{Hg}(\mathrm{II})$ by cyanobacteria, Applied and Environmental Microbiology 73 (1) (2007) 243-249.

[67] H.A. Kaoud, K.M.A. Mahran, A. Rezk, M.A. Khalf, bioremediation the toxic effect of mercury on liver histopathology, some hematological parameters and enzymatic activity in Nile tilapia, Oreochromis niloticus, Researcher 4 (1) (2012) 60-69.

[68] S.K. Gupta, A.K. Dwivedi, R.B. Deshmukh, R.M. Patrikar, Lab on chip for detection of E. coli using capacitance modulation, in: Comsol Conference Bengalore, India, November 2-3, 2012 